\title{
A Sensitive and Selective Label-Free Electrochemical DNA Biosensor for the Detection of Specific Dengue Virus Serotype 3 Sequences
}

\section{Natália Oliveira $^{1, *}$, Elaine Souza ${ }^{2}$, Danielly Ferreira ${ }^{1}$, Deborah Zanforlin ${ }^{1}$, Wessulla Bezerra ${ }^{1}$, Maria Amélia Borba ${ }^{1}$, Mariana Arruda ${ }^{1}$, Kennya Lopes ${ }^{3}$, Gustavo Nascimento ${ }^{1}$, Danyelly Martins ${ }^{1,4}$, Marli Cordeiro ${ }^{4}$ and José Lima-Filho ${ }^{1,4}$}

1 Laboratório de Imunopatologia Keizo Asami (LIKA), Universidade Federal de Pernambuco-UFPE, Av. Prof. Moraes Rego, s/n, Campus da UFPE, 50670-901 Recife, PE, Brazil;

E-Mails: daniellylsantos@hotmail.com (D.F.); deborahzanforin@gmail.com (D.Z.); wessullas@yahoo.com.br (W.B.); mariameliaborba@gmail.com (M.A.B.); mariana.s.arruda@gmail.com (M.A.); galvesn23@gmail.com (G.N.); bruneska@prospecmol.org (D.M.); joseluiz60@mac.com (J.L.-F.)

2 Universidade Federal de Alagoas (UFAL), Campus Arapiraca, Av. Manoel Severino Barbosa, s/n, Bom Sucesso, 57.309-005 Arapiraca, AL, Brazil; E-Mail: elainevms@yahoo.com.br

3 Departamento de Virologia e Terapia Experimental (LAVITE), Centro de Pesquisas Aggeu Magalhães (CPqAM), Fundação Oswaldo Cruz (Fiocruz)—Pernambuco, Av. Professor Moraes Rego, s/n, Campus da UFPE, 50.670-420 Recife, PE, Brazil; E-Mail: kennya.genne@bol.com.br

4 Departamento de Bioquímica, Universidade Federal de Pernambuco-UFPE, Av. Professor Moraes Rego, s/n, Campus da UFPE, CEP: 50670-901 Recife, PE, Brazil; E-Mail: Marli@cpqam.fiocruz.br

* Author to whom correspondence should be addressed; E-Mail: nataliacybelle.89@gmail.com Tel: +55-81-2101-2508; Fax: +55-81-2126-8000.

Academic Editor: Stephen Holler

Received: 1 March 2015 / Accepted: 23 June 2015 / Published: 1 July 2015

\begin{abstract}
Dengue fever is the most prevalent vector-borne disease in the world, with nearly 100 million people infected every year. Early diagnosis and identification of the pathogen are crucial steps for the treatment and for prevention of the disease, mainly in areas where the co-circulation of different serotypes is common, increasing the outcome of dengue hemorrhagic fever (DHF) and dengue shock syndrome (DSS). Due to the lack of fast and inexpensive methods available for the identification of dengue serotypes, herein we report
\end{abstract}


the development of an electrochemical DNA biosensor for the detection of sequences of dengue virus serotype 3 (DENV-3). DENV-3 probe was designed using bioinformatics software and differential pulse voltammetry (DPV) was used for electrochemical analysis. The results showed that a 22-m sequence was the best DNA probe for the identification of DENV-3. The optimum concentration of the DNA probe immobilized onto the electrode surface is $500 \mathrm{nM}$ and a low detection limit of the system (3.09 nM). Moreover, this system allows selective detection of DENV-3 sequences in buffer and human serum solutions. Therefore, the application of DNA biosensors for diagnostics at the molecular level may contribute to future advances in the implementation of specific, effective and rapid detection methods for the diagnosis dengue viruses.

Keywords: dengue fever; DNA biosensors; differential pulse voltammetry; electrochemical detection; guanine oxidation

\section{Introduction}

Dengue fever is the most prevalent vector-borne disease in the world. The World Health Organization (WHO) estimates that some 100 million people are infected every year; however, some studies have predicted that this number could be greatly underestimated, and is actually closer to 390 million [1-3]. The distribution of the disease is mainly in tropical and subtropical regions and recently, it is has been increasingly seen in urban and semi-urban areas. All these factors have contributed to reveal dengue fever as a major international public health problem $[1,2,4,5]$.

The infection is caused by a single stranded RNA-virus (DENV) of about $10.7 \mathrm{~kb}$, which belongs to the Flaviviridae family, with approximately four antigenically distinct serotypes (DENV-1-DENV-4) [6,7]. The disease exhibits a wide range of symptoms, such as fever, headache and myalgia, which are the most common in classic dengue. Nevertheless, it can also shows more severe manifestations, like in dengue hemorrhagic fever (DHF) or dengue shock syndrome (DSS), which present life-threatening symptoms, such as bleeding, thrombocytopenia and vascular leakage [8-10].

Early diagnosis and identification of the pathogen are necessary for the prevention and treatment of patients, as well as for the avoidance of new outbreaks and emergence of severe cases of dengue, since it is known that the co-circulation of different serotypes in an area increases the possibility of DHF and DSS outcomes [11,12].

Methods to confirm dengue virus infection may involve detection of the virion, viral RNA, antigens or antibodies [13]. Virus detection by cell culture, viral nucleic acid or antigen detection (nonstructural protein 1 or NS1 antigen) can be used to confirm dengue infection in the acute phase of the illness (0-7 days following the onset of the symptoms) $[14,15]$. In the later phase of the disease, serologic tests are more applied and preferred for diagnosis, as the sensitivity of virus isolation and antigen reactivity decreases [16]. Viral antigen (NS1) detection assays are rapid, reliable and easy to perform, however, they cannot allow to distinguish between different viral serotypes [17,18].

Viral isolation, although considered the gold standard diagnostic method, is time-consuming and highly complex compared with other direct virus detection techniques $[1,19]$. On the other hand, the 
RT-PCR assay is widely used, it allows the detection of low copies of viral genes in less than $48 \mathrm{~h}$ [20]. However, both techniques are costly and labor-intensive, but they are more specific than serologic methods used for antibody detection and allow one to differentiate between the various dengue virus serotypes [21].

Application of DNA biosensors has emerged as an alternative method to the current molecular biology techniques [22,23]. These devices consist of a single-stranded DNA molecule (ssDNA) attached to a transducing surface that is able to detect a specific nucleic acid sequence, based on DNA hybridization events. Currently, there is a growing interest in developing label-free methods for DNA detection, considering their rapidness, easiness, low cost and minimal sample preparation requirements, compared to labeling methods, where the properties of the modified macromolecules often change, which may result in total loss of bioactivity or stability [24,25]. Label-free approaches rely on the direct detection of intrinsic electrochemical properties of DNA (e.g., oxidation of purine bases, particularly guanine) or on changes in some of the interfacial properties after hybridization. In addition, interference with the biological recognition between DNA molecules is minimized. Nevertheless, in labeling methods, these undesirable effects are more likely to occur due to steric hindrance and blocking of the binding sites [26-28].

Consequently, since biosensors allow to detect and identify DNA sequences in a fast and simple way, herein we report the first step to develop a cost-effective, sensitive and label-free electrochemical DNA biosensor for the detection of DENV-3 sequences in biological samples, as a part of an ongoing research previously published [29].

\section{Experimental Section}

\subsection{Design of a Specific DENV-3 DNA Probe}

The complete genomes of dengue virus serotype 3, corresponding to GenBank accession numbers AY099336, AY099337, AY099338S1,AY099338S2, AY099339S1, AY099339S2, AY099340S1, AY099340S2, AY09934S1, AY099342S1 were obtained from the National Center for Biotechnology Information (NCBI) database. These sequences correspond to strains that were introduced in the American continent, and caused the disease outbreaks in 2002 [30,31]. CLC Main Workbench v.6.0 software was used to analyze common sequences among those dengue genomes, by using an alignment tool. Then, a specific DNA probe for DENV-3 was selected by comparison of the homologous sequences with other organisms, using Basic Local Alignment Search Tool (BLAST). DENV-3 complementary (target) and non-complementary sequences were also designed using the same method.

\subsection{Reagents and Materials}

All chemicals were of reagent grade quality and were used directly as received without further purification. Tris base was obtained from Promega (Fitchburg, WI, USA) and sodium acetate was obtained from Sigma-Aldrich (St. Louis, MO, USA) DENV-3 probes were purchased as lyophilized powder from IDT Technologies (Coraville, IA, USA). The stock and diluted solutions (25 $\mathrm{nM}$ ) were prepared in $0.5 \mathrm{M}$ acetate buffer $(\mathrm{pH}$ 5.0) and kept frozen. Ultrapure RNAse/DNAse-free water was used in all buffer solutions. After bioinformatics analysis, the following DNA sequences were used in this study: 
DENV-3 probe: 5'-TAA CAT CAT CAT GAG ACA GAG C-3'

DENV-3 target: 5'-GCT CTG TCT CAT GAT GAT GTT A-3'

Non-complementary sequence: 5'-TCT CTT GTT TAA GAC AAC AGA G-3'

Human serum used in this study was obtained from blood samples provided by the pathogenic virus collection of Centro de Pesquisas Aggeu Magalhães (CPqAM). Serum solutions were prepared by centrifugation at $3500 \mathrm{rpm}$ for $5 \mathrm{~min}$ at $20^{\circ} \mathrm{C}$ (3500 rpm for $5 \mathrm{~min}$ ), in which the obtained supernatant was collected from each sample, and stored at $23{ }^{\circ} \mathrm{C}$ until further used for experiments testing.

\subsection{Apparatus}

Experiments were carried out using a PGSTAT302 potentiostat (METROHM Autolab, Utrecht, The Netherlands) with the GPES 4.9.007 software as a graphic interface. The electrochemical device was composed by a two-electrode system: A pencil graphite electrode (PGE) as a working electrode and silver/chloride silver electrode as a reference electrode. Each measurement consisted of a cycle of activation/immobilization/hybridization/detection by using a fresh PGE surface. All the experiments were performed in triplicate, at room temperature $\left(23^{\circ} \mathrm{C}\right)$.

\subsection{Procedure}

\subsubsection{Preparation of Electrodes and Pre-Treatment of PGE}

PGEs were obtained from Mercur (Santa Cruz do Sul, Brazil), as a pencil graphite lead type 4 B. Briefly, PGEs were produced by cutting graphite lead in pieces of $3 \mathrm{~cm}$ and polishing them with an emery polishing disc (Dremel, Mount Prospect, IL,USA). The PGEs were then washed with ultrapure water to remove any contaminant present on the surface of the working electrode. The reference electrode was made by immersing a golden pin into an $\mathrm{Ag} / \mathrm{AgCl}$ ink (Henkel Acheson, Hemel Hempstead, UK) and dried at $40{ }^{\circ} \mathrm{C}$ overnight. The polished surface of PGEs was pre-treated by applying a potential of $+1.80 \mathrm{~V}$ for $5 \mathrm{~min}$ in $0.5 \mathrm{M}$ acetate buffer solution ( $\mathrm{pH}$ 5.0) [32-34].

\subsubsection{DNA Probe Immobilization onto PGE Surface}

Immobilization of DENV-3 probe onto the PGE surface was performed by immersing the activated PGE in acetate buffer solution, with different concentrations of DENV-3 probes (250-1000 nM), by applying a fixed potential of $+0.5 \mathrm{~V}$ for $300 \mathrm{~s}$ onto the electrode surface.

\subsubsection{DNA Hybridization with Complementary and Non-Complementary Sequences}

The hybridization of the immobilized DNA probe on the electrode (PGE/DENV-3 probe) was performed by immersing the electrode in an Eppendorf tube containing $70 \mu \mathrm{L}$ of DENV-3 target sequences diluted in acetate buffer. The hybridization reaction was then carried out in a thermomixer, stirring at $300 \mathrm{rpm}$, under a specific annealing temperature of $52{ }^{\circ} \mathrm{C}$, for $10 \mathrm{~min}$. This same procedure was adopted to evaluate the hybridization of the PGE/DENV-3 probe with non-complementary sequences, as well as buffer solutions containing a mix of both $75 \mathrm{nM}$ of DENV-3 complementary and non-complementary sequences (mixed DNA solution). 


\subsubsection{Detection of Complementary and Non-Complementary Sequences in Human Serum}

As a way to evaluate the efficiency of the system to detect DENV-3 sequences in biological samples on the electrode surface, the complementary and non-complementary DNA sequences were diluted in human serum (75 $\mathrm{nM}$ concentration) and the hybridization assay was conducted using the same conditions described previously. This procedure was also adopted for tests human serum solutions mixed with both target and non-complementary sequences.

\subsection{Electrochemical Analysis}

Differential pulse voltammetry (DPV) was used for electrochemical analysis in this study. Current peaks were recorded after applying a potential range of +0.5 up to $+1.2 \mathrm{~V}$ at a scan rate of $0.05 \mathrm{~V} / \mathrm{s}$ onto

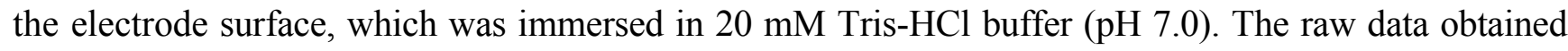
with DPV technique was treated using the Savitzky and Golay filter (level 2) of the GPES software, followed by moving the average baseline correction using a peak width of $0.01 \mathrm{~V}$ [35].

\subsection{Statistical Data Analysis}

Experimental data were analyzed with Statistica 8.0 software (StatSoft, Tulsa, OK, USA) using parametric tests; Tukey's test was used to compare multi-independent group data, and a level of $p<0.05$ was considered significant. The reproducibility of the system was expressed as the coefficient of variation inter-assay (CV), which was calculated over three independent assays on the probe-modified PGEs.

\section{Results and Discussion}

\subsection{Bioinformatics Analysis of DENV-3 DNA Probes}

The design of DNA probes is one of the crucial steps in the development of a biosensor, because it determines the specificity of the device [36]. For genosensors, this can be achieved using bioinformatics analysis based on whole genome sequencing, in a way to predict the most specific region that is able to produce a steady double-strand DNA with the pathogen [37,38]. In this work, DNA probes specific for DENV-3 were designed mainly by using CLC Main Workbench software, based on a sequence alignment tool to identify regions of similarity between the dengue strains. After that, DNA sequences from the strains that showed specificity only for DENV-3 were compared with other organism genomes using BLAST tool, in order to exclude any correlations. Finally, the Oligonucleotide Properties Calculator (Oligo Calc) software (Northwestern University, IL, USA) was used to provide physical properties information of the selected DENV-3 sequences, in a way to establish the best match of DNA probe for biosensors. Figure 1 shows a flowchart containing the criteria of selection of DENV-3 probes used in this study. 


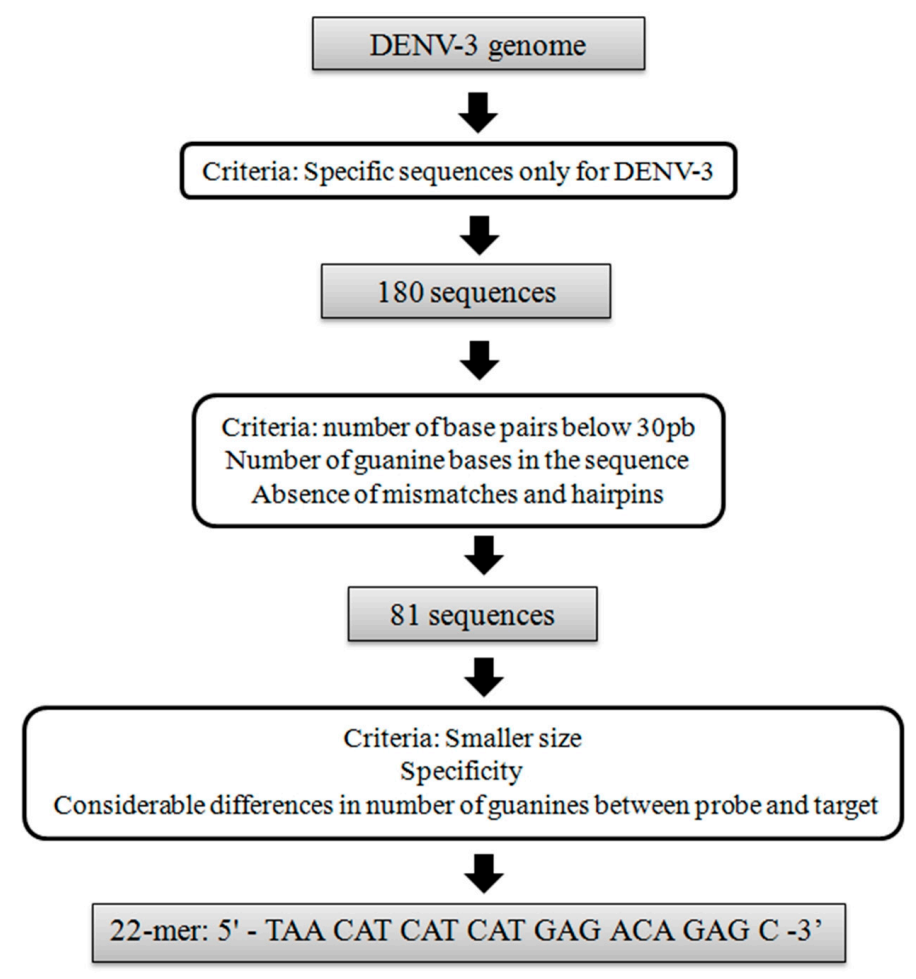

Figure 1. Flowchart of the selection criteria used to design the DENV-3 probe.

First, it was shown that 180 DNA sequences were specific only for dengue virus serotype 3 . Among these, 81 were selected as DNA probes, based on the number of base pairs of the sequence, number of guanine bases and the absence of mismatches and hairpins. Finally, a 22-m oligonucleotide was selected to detect DENV-3, with the following sequence: 5'-TAA CAT CAT CAT GAG ACA GAG C-3'. This sequence was selected due to its suitable features that are desirable for electrochemical biosensors, such as shorter base pair length, high specificity and a considerable difference in the number of guanine base between the probe and target sequences, which is important to discriminate between ssDNA and dsDNA onto the PGE surface $[33,39,40]$.

In addition, this probe was targeted to detect sequences from the envelope (E) gene, which is responsible for binding and fusion to host cell membranes [4,41]. This particular gene was chosen because of it is highly conserved sequence, which suffers less mutation process rather than other parts of dengue genome. Viral gene regions that interact with specific host cells are evolutionarily constrained, mainly in viruses that infect multiple organisms, like dengue virus. This is important to be considered in the development of DNA biosensors to detect dengue virus, once that it determines the selectivity and specificity of the method, avoiding cross-reactivity with non-related organisms [42-44].

\subsection{Effect of DENV-3 Probes Concentration on Immobilization on the PGE}

The immobilization of a biological element on the electrode is the first step to be considered in the development of a biosensor [45]. Determination of the optimal probe concentration is crucial to ensure a high performance of DNA biosensors, and reduce any interference in the electrochemical response of the system $[46,47]$. Thus, the effect of DENV-3 probes concentration was also investigated in this study. 
Figure 2 shows current peaks of different DENV-3 probe concentrations on the PGE surface. As the electrochemical analysis in this study relies on label-free oxidation of guanine bases, the acquisition of higher current signals for DNA probes is well-suited for this system [29,48-50]. The results show that the current gradually rises with the increase of the probe concentration from $250 \mathrm{nM}$ up to $500 \mathrm{nM}$, reaching the highest electrochemical signal of $777 \pm 8.6 \mathrm{nA}$ at $500 \mathrm{nM}$. The result obtained at $500 \mathrm{nM}$ was also statistically different from that obtained at $750 \mathrm{nM}(p=0.000178)$. However, the decrease in the current peaks at higher concentrations of DNA probes after $500 \mathrm{nM}$ could be due to the steric hindrance between the nitrogenous bases and the transducer. This prevents the electrons produced by the oxidation process to access the electrode surface [51-55]. Therefore, a concentration of $500 \mathrm{nM}$ was selected as the optimal probe concentration for DNA immobilization on the PGE.

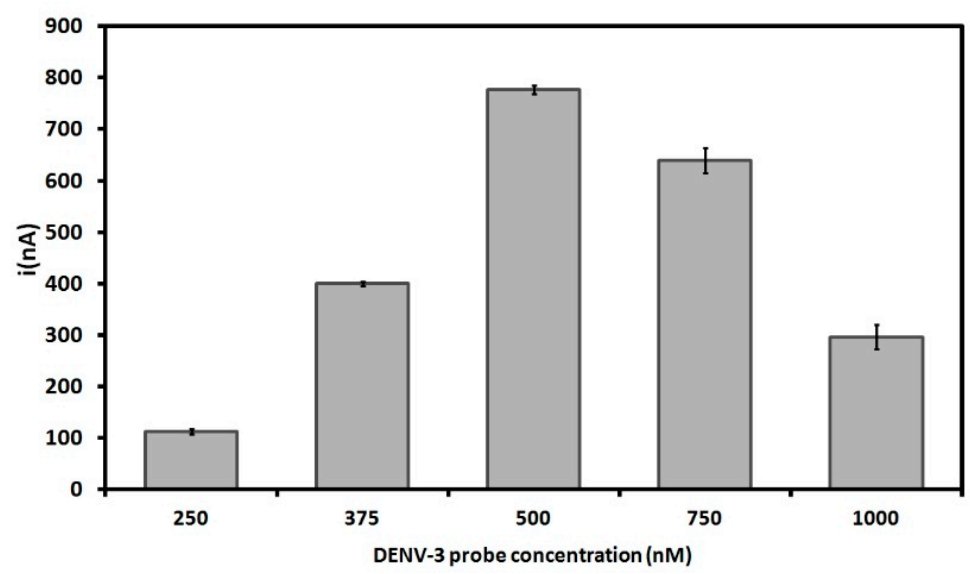

Figure 2. Electrochemical signals of different concentrations of DENV-3 probe onto pencil graphite electrodes (PGE). Differential pulse voltammetry (DPV) was used for electrochemical analysis based on guanine oxidation. Experimental conditions: Scanning potential range between $+0.5 \mathrm{~V}$ and $+1.2 \mathrm{~V}$ and scan rate of $0.05 \mathrm{~V} / \mathrm{s}$. The results represent the average of triplicates carried out at each DENV-3 probe concentration.

\subsection{Electrochemical Analysis of Hybridization Assays}

In this study, the biosensor performance was analyzed through the hybridization reaction between the DENV-3 probe and the complementary DENV-3 oligonucleotide. Hybridization was carried out with different amounts of the target sequence and this reaction was performed in an electrochemical cell containing $20 \mathrm{mM}$ Tris-HCl buffer ( $\mathrm{pH}$ 7.0). The electrochemical signals based on guanine oxidation are displayed in Figure 3. The results showed that the current peaks increase with the increasing concentration of the target sequence (10 nM to $500 \mathrm{nM})$; the highest concentration exhibited the highest current peak of the system $(135 \pm 2.15 \mathrm{nA})$. However, at concentrations higher than $500 \mathrm{nM}$, there is a decrease in the electrochemical signal that could be due to electrostatic hindrance of DNA molecules on the PGE surface $[39,53,56]$.

The linear regression of the current peaks obtained from different concentrations of DENV-3 target is shown in the inset of Figure 3. The calibration curve (described by the equation $y=0.8962 x+24.979$ ) is linear between $10 \mathrm{nM}$ and $100 \mathrm{nM}$, with a correlation coefficient of $0.9883(p<0.00536, n=5)$. A detection limit of $3.09 \mathrm{nM}$ could be estimated with the following equation: $3 \mathrm{~s} / \mathrm{m}$, where $s$ is the standard deviation of 
most reproducible current peak result (corresponding to $75 \mathrm{nM}$ concentration) and $m$ is the slope of the linear regression [57]. The same experimental conditions were used to estimate the reproducibility of the method, which was $1.01 \%$, indicating, thus, the significant reproducibility of the method.

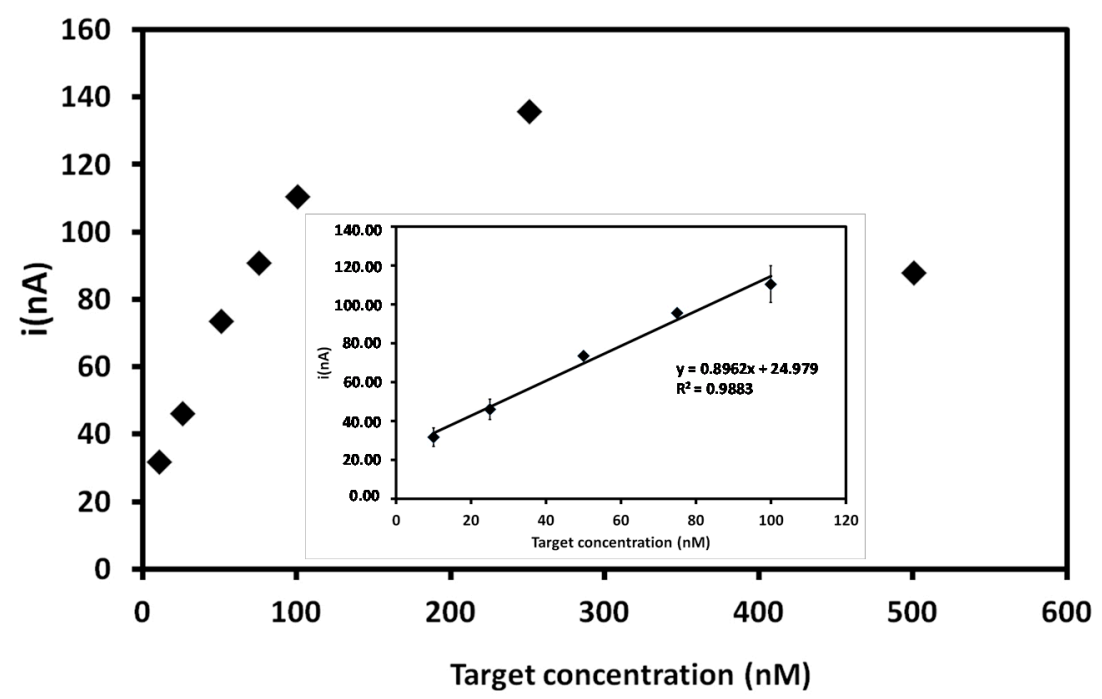

Figure 3. Current signals obtained for different DENV-3 target sequence concentrations after hybridization with probe-modified PGEs. Inset: Related calibration graph at a concentration range of 10-100 $\mathrm{nM}$ for the target sequence. Experimental conditions: Scanning potential range between $+0.5 \mathrm{~V}$ and $+1.2 \mathrm{~V}$ and scan rate of $0.05 \mathrm{~V} / \mathrm{s}$.

Figure 4 displays electrochemical signals of probe-modified PGE before and after hybridization with $250 \mathrm{nM}$ of the target. A decrease of $83 \%$ in the current signal was observed after the reaction with the DENV-3 target; this is due to the fact that oxidizable regions of guanine bases in the ssDNA (777 nA) are bound through hydrogen bonds that held the double chain together, thus decreasing the electrochemical signal of the dsDNA (135 nA) on the electrode surface [24,58-60].

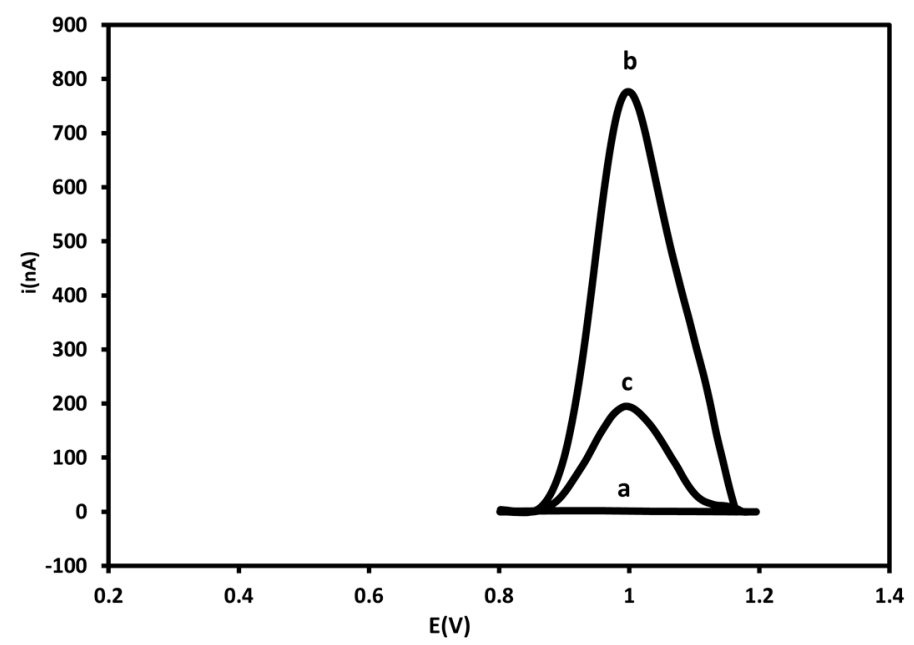

Figure 4. Differential pulse voltammograms corresponding to bare PGE (a), probe-modified PGE before (b) and after hybridization with $250 \mathrm{nM}$ of target sequence (c) in $20 \mathrm{mM}$ Tris-HCl buffer solution ( $\mathrm{pH}$ 7.0). Experimental conditions: Scanning potential range between $+0.5 \mathrm{~V}$ and $+1.2 \mathrm{~V}$ and scan rate of $0.05 \mathrm{~V} / \mathrm{s}$. 
Furthermore, as is seen in Table 1, the present sensor has a lower detection limit (3.09nM) compared to other electrochemical DNA biosensors.

Table 1. Comparison of the analytical performance of different electrochemical DNA biosensors.

\begin{tabular}{|c|c|c|c|c|c|}
\hline Nucleic Acid Biosensor & Electrode & $\begin{array}{c}\text { Electrochemical } \\
\text { Method }\end{array}$ & $\begin{array}{c}\text { Linear Range of } \\
\text { Hybridization }\end{array}$ & $\begin{array}{l}\text { Detection } \\
\text { Limit }\end{array}$ & Reference \\
\hline $\begin{array}{c}\text { Single-walled carbon } \\
\text { nanotubes-polymer modified } \\
\text { graphite electrodes for DNA } \\
\text { hybridization }\end{array}$ & $\mathrm{PGE}^{\mathrm{a}}$ & DPV $^{d}$ & $50-200 \mu \mathrm{g} / \mathrm{mL}$ & $5.14 \mu \mathrm{M}$ & {$[61]$} \\
\hline $\begin{array}{l}\text { Hybridization biosensor for } \\
\text { detection of hepatitis B virus }\end{array}$ & $\mathrm{GCE}^{\mathrm{b}}$ & DPV & $0.36-1.32 \mu \mathrm{M}$ & $19.4 \mathrm{nM}$ & {$[62]$} \\
\hline $\begin{array}{l}\text { Brilliant cresyl blue as } \\
\text { electroactive indicator in } \\
\text { electrochemical DNA } \\
\text { oligonucleotide sensors }\end{array}$ & $\mathrm{CPE}^{\mathrm{c}}$ & DPV & $10 \mathrm{nM}-5 \mu \mathrm{M}$ & $9 \mathrm{nM}$ & [63] \\
\hline $\begin{array}{c}\text { Label-free DNA detection } \\
\text { based on zero current } \\
\text { potentiometry }\end{array}$ & PGE & $\mathrm{LSV}^{\mathrm{e}}$ & $10 \mathrm{nM}-1 \mu \mathrm{M}$ & $6.9 \mathrm{nM}$ & [64] \\
\hline $\begin{array}{c}\text { DNA biosensor detection of } \\
\text { DENV-3 sequences onto } \\
\text { PGE surfaces }\end{array}$ & PGE & DPV & $10-100 \mathrm{nM}$ & $3.09 \mathrm{nM}$ & This work \\
\hline
\end{tabular}

\subsection{Selectivity Study}

In a way to evaluate the selectivity of the DENV-3 biosensor, hybridization tests were performed with a non-complementary sequence. DPV voltammograms for bare PGE, probe-modified PGE before and after hybridization with DENV-3 target and non-complementary sequence are displayed in Figure 5. It was verified that no electrochemical signal was recorded with bare PGE, which is in agreement with the absence of DNA on the electrode surface. Probe-modified PGE presented the highest current peak of the system, whereas the probe-modified PGE after hybridization with target sequence showed a decrease in the current signal, as discussed previously.

As shown in Figure 5, a significant difference in the voltammetric signal was observed after hybridization of DENV-3 probe with the non-complementary sequence (600 nA) when compared with the complementary DNA (135 nA); however, the signal was slightly lower compared to the probe-modified electrode $(777 \mathrm{nA})$. This may be attributed to some unspecific hybridization of non-complementary sequences with the probe. Nevertheless, the target sequence is clearly able to form a steady dsDNA on the electrode surface. Moreover, a decrease in the current peak was also noticed when the probe-modified PGE was added to the mixed DNA solution ( $230 \mathrm{nA})$ when compared with the probe-modified electrode. Therefore, these results can confirm the ability of the PGE-modified biosensor to detect selectively dengue virus serotype $3[34,61,62]$. 


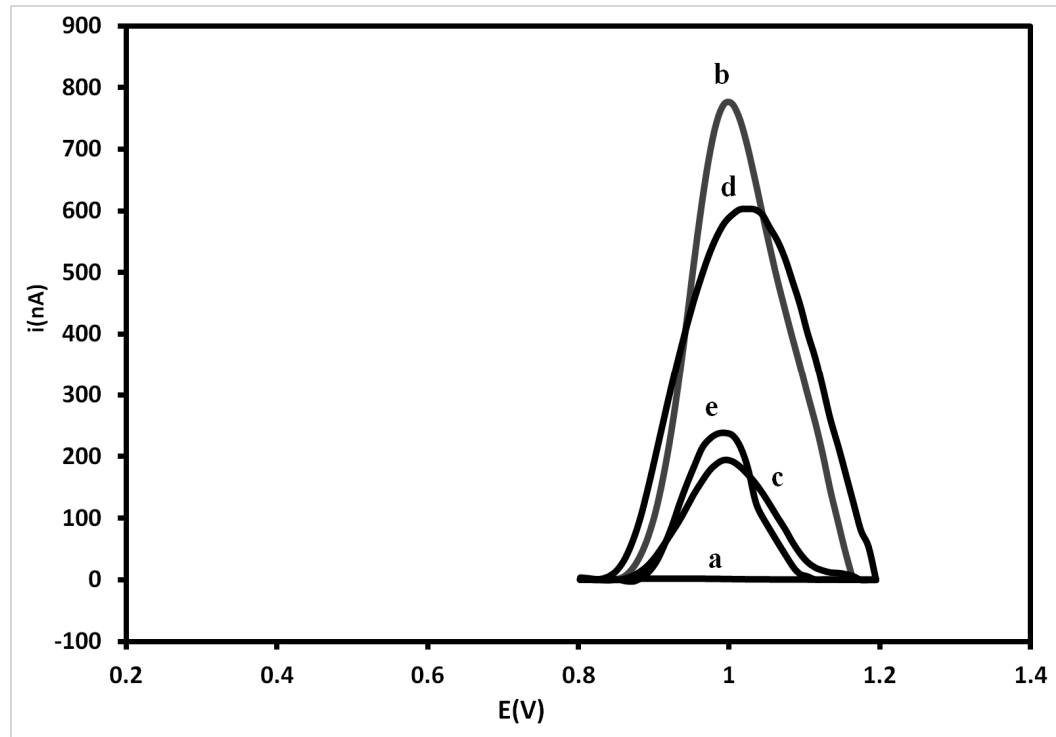

Figure 5. Differential pulse voltammograms for guanine oxidation of (a) bare PGE; (b) probe-modified PGE; (c) probe-modified PGE after hybridization with DENV-3 sequence; (d) non-complementary sequence and (e) a mixed solution of DENV-3 sequence and non-complementary sequence. Experimental conditions: Scanning potential range between $+0.5 \mathrm{~V}$ and $+1.2 \mathrm{~V}$ and scan rate of $0.05 \mathrm{~V} / \mathrm{s}$.

\subsection{Electrochemical Measurement of Target Hybridization in Human Serum Solutions}

In order to evaluate the efficiency of the probe surface for biosensing applications and in an attempt to test the performance if the biosensor for the detection DENV-3 in real samples, DPV was used to investigate DNA hybridization on PGE surface using human serum. This assay was tested with $75 \mathrm{nM}$ of target sequence, non-complementary sequences and a solution mixed of both target and non-complementary sequences.

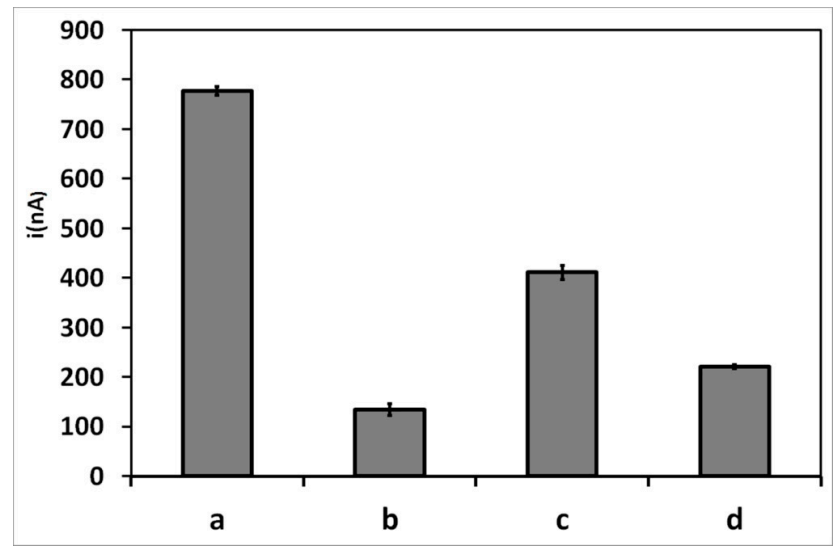

Figure 6. Current peaks related to guanine oxidation of the probe-modified-PGE after (a) and before hybridization with DENV-3 (b); in the presence of non-complementary sequences (c) and in a solution mixed with DENV-3 and non-complementary sequences (d), all diluted in human serum. Experimental conditions: Scanning potential range between +0.5 $\mathrm{V}$ and $+1.2 \mathrm{~V}$ and scan rate of $0.05 \mathrm{~V} / \mathrm{s}$. 
As shown in Figure 6, the biosensor displays the same electrochemical behavior observed previously in Tris- $\mathrm{HCl}$ buffer solutions. However, all the current signals of the probe-modified PGE after hybridization with the complementary, non-complementary sequences and mixed DNA solution diluted in human serum presented a slight decrease (134, 410.8 and $221 \mathrm{nA}$, respectively) when compared with those diluted in acetate buffer $(135,600$ and $230 \mathrm{nA}$, respectively). This could be due to the hybridization kinetics and the efficiency of the PGE surface, which could be affected by non-specific adsorption of plasma proteins, and this may interfere with the detection of the electrochemical signal [63]. However, such interference with the detection of DNA molecules was observed previously with the optical DNA biosensor developed by Gong et al. [64,65]. Thus, these results confirm the high selectivity and sensitivity of the electrochemical DNA biosensor developed herein.

\section{Conclusions}

A sensitive DNA biosensor based on electrochemistry for the detection of dengue virus serotype 3 was proposed in the present study. A pencil graphite electrode, modified with a probe designed specifically for DENV-3, was able to identify selectively target sequences of the virus, with a low detection limit of $3.09 \mathrm{nM}$. Moreover, the probe-modified PGE allowed to detect specifically complementary sequences of the target DNA spiked with human serum.

The sensitivity of this assay can be further improved by testing other electrode materials, such as gold, platinum and grapheme electrodes. In addition, screen-printed electrodes could be also used for the implementation of a portable system. Therefore, the application of biosensors for the diagnosis of dengue virus at the molecular level may contribute to the future development and advancement of effective and rapid detection methods.

\section{Acknowledgments}

The authors would like to thank Centro de Pesquisas Aggeu Magalhães (CPqAM) that kindly provided biological samples for this project. In addition, they would like to thank Fundação de Amparo à Pesquisa do Estado de Pernambuco (FACEPE), Conselho Nacional de Desenvolvimento Científico e Tecnológico $(\mathrm{CNPq})$ and Laboratório de Imunopatologia Keizo Asami (LIKA) for providing financial support and Graziella El Khoury for reviewing of the manuscript for English language.

\section{Author Contributions}

N.O. designed and performed the majority of the experiments. D.Z. performed bioinformatics analysis. W.B. and M.B. prepared PGEs, buffer solutions and performed part of electrochemical experiments. M.T. and K.T. were responsible for selecting and supplying biological samples for the experiments. D.M. processed human serum samples. G.N. and D.F. were responsible for statistical data analysis. N.O., E.S., M.A. and J.L.-F. drafted and revised critically the manuscript.

\section{Conflicts of Interest}

The authors declare no conflict of interest. 


\section{References}

1. WHO. Dengue-Guidelines for Diagnosis, Treatment, Prevention and Control; WHO Press: Geneva, Switzerland, 2009; p. 147.

2. Sariol, C.A.; White, L.J. Utility, limitations, and future of non-human primates for dengue research and vaccine development. Front. Immunol. 2014, 5, 452, doi:10.3389/fimmu.2014.00452.

3. Bhatt, S.; Gething, P.W.; Brady, O.J.; Messina, J.P.; Farlow, A.W.; Moyes, C.L.; Drake, J.M.; Brownstein, J.S.; Hoen, A.G.; Sankoh, O.; Myers, M.F.; et al. The global distribution and burden of dengue. Nature 2013, 496, 504-507.

4. Vasilakis, N.; Cardosa, J.; Hanley, K.A.; Holmes, E.C.; Weaver, S.C. Fever from the forest: Prospects for the continued emergence of sylvatic dengue virus and its impact on public health. Nat. Rev. Microbiol. 2011, 9, 532-541.

5. Chien, L.C.; Yu, H.L. Impact of meteorological factors on the spatiotemporal patterns of dengue fever incidence. Environ. Int. 2014, 73, 46-56.

6. Cedillo-Barrón, L.; García-Cordero, J.; Bustos-Arriaga, J.; León-Juárez, M.; Gutiérrez-Castañeda, B. Antibody response to dengue virus. Microbes Infect. 2014, 16, 711-720.

7. Rovida, F.; Percivalle, E.; Campanini, G.; Piralla, A.; Novati, S.; Muscatello, A.; Baldanti, F. Viremic Dengue virus infections in travellers: Potential for local outbreak in Northern Italy Dengue-1 Dengue-4. J. Clin. Virol. 2011, 50, 76-79.

8. Ashley, E.A. Trends in Anaesthesia and Critical Care Dengue fever. Trends Anaesth. Crit. Care 2011, 1, 39-41.

9. Qing, X.; Sun, N.; Yeh, J.; Yue, C.; Cai, J. Dengue fever and bone marrow myelofibrosis. Exp. Mol. Pathol. 2014, 97, 208-210.

10. Halstead, S.B. Dengue. Lancet 2007, 370, 1644-1652.

11. Arora, P.; Sindhu, A.; Dilbaghi, N.; Chaudhury, A. Biosensors as innovative tools for the detection of food borne pathogens. Biosens. Bioelectron. 2011, 28, 1-12.

12. Chakravarti, A.; Arora, R.; Luxemburger, C. Fifty years of dengue in India. Trans. R. Soc. Trop. Med. Hyg. 2012, 106, 273-282.

13. Verma, R.; Sahu, R.; Holla, V. Neurological manifestations of dengue infection: A review. J. Neurol. Sci. 2014, 346, 26-34.

14. Pechansky, F.; Duarte, P.D.C.A.V.; de Boni, R.; Leukefeld, C.G.; von Diemen, L.; Bumaguin, D.B.; Kreische, F.; Hilgert, J.B.; Bozzetti, M.C.; Fuchs, D.F.P. Predictors of positive Blood Alcohol Concentration (BAC) in a sample of Brazilian drivers. Rev. Bras. Psiquiatr. 2012, 34, 277-285.

15. Ferraz, F.O.; Bomfim, M.R.Q.; Totola, A.H.; Ávila, T.V.; Cisalpino, D.; Pessanha, J.E.M.; da Glória de Souza, D.; Teixeira Júnior, A.L.; Nogueira, M.L.; Bruna-Romero, O.; et al. Evaluation of laboratory tests for dengue diagnosis in clinical specimens from consecutive patients with suspected dengue in Belo Horizonte, Brazil. J. Clin. Virol. 2013, 58, 41-46.

16. Peeling, R.W.; Artsob, H.; Pelegrino, J.L.; Buchy, P.; Cardosa, M.J.; Devi, S.; Enria, D.A.; Farrar, J.; Gubler, D.J.; Guzman, M.G.; et al. Evaluation of diagnostic tests: Dengue. Nat. Rev. Microbiol. 2010, 8, S30-S37.

17. Wattal, C.; Goel, N. Infectious Disease Emergencies in Returning Travelers-Special Reference to Malaria, Dengue Fever and Chikungunya. Med. Clin. North Am. 2012, 96, 1225-1255. 
18. Korhonen, E.M.; Huhtamo, E.; Virtala, A.M.K.; Kantele, A.; Vapalahti, O. Approach to non-invasive sampling in dengue diagnostics: Exploring virus and NS1 antigen detection in saliva and urine of travelers with dengue. J. Clin. Virol. 2014, 61, 353-358.

19. Shenoy, B.; Menon, A.; Biradar, S. Science Direct Diagnostic utility of dengue NS1 antigen. Pediatr. Infect. Dis. 2014, 6, 110-113.

20. Hapugoda, M.D.; de Silva, N.R.; Khan, B.; Damsiri Dayanath, M.Y.; Gunesena, S.; Prithimala, L.D.; Abeyewickreme, W. A comparative retrospective study of RT-PCR-based liquid hybridization assay for early, definitive diagnosis of dengue. Trans. R. Soc. Trop. Med. Hyg. 2010, 104, 279-282.

21. Back, A.T.; Lundkvist, A. Dengue viruses-An overview. Infect. Ecol. Epidemiol. 2013, 1, 1-21.

22. Siddiquee, S.; Rovina, K.; Yusof, N.A.; Rodrigues, K.F. Nanoparticle-enhanced electrochemical biosensor with DNA immobilization and hybridization of Trichoderma harzianum gene. Sens. Bio-Sens. Res. 2014, 2, 16-22.

23. Teles, F.S.R.R. Biosensors and rapid diagnostic tests on the frontier between analytical and clinical chemistry for biomolecular diagnosis of dengue disease: A review. Anal. Chim. Acta 2011, 687, $28-42$.

24. Lucarelli, F.; Tombelli, S.; Minunni, M.; Marrazza, G.; Mascini, M. Electrochemical and piezoelectric DNA biosensors for hybridisation detection. Anal. Chim. Acta 2008, 609, 139-159.

25. Souada, M.; Piro, B.; Reisberg, S.; Anquetin, G.; Noël, V.; Pham, M.C. Label-free electrochemical detection of prostate-specific antigen based on nucleic acid aptamer. Biosens. Bioelectron. 2014, 68C, 49-54.

26. Tosar, J.P.; Keel, K.; Laíz, J. Two independent label-free detection methods in one electrochemical DNA sensor. Biosens. Bioelectron. 2009, 24, 3036-3042.

27. Sadik, O.A; Aluoch, A.O.; Zhou, A. Status of biomolecular recognition using electrochemical techniques. Biosens. Bioelectron. 2009, 24, 2749-2765.

28. Conde, J.; Edelman, E.R.; Artzi, N. Target-responsive DNA/RNA nanomaterials for microRNA sensing and inhibition: The jack-of-all-trades in cancer nanotheranostics? Adv. Drug Deliv. Rev. 2015, 81C, 169-183.

29. Souza, E.; Nascimento, G.; Santana, N.; Ferreira, D.; Lima, M.; Natividade, E.; Martins, D.; Lima-Filho, J. Label-free electrochemical detection of the specific oligonucleotide sequence of dengue virus type 1 on pencil graphite electrodes. Sensors 2011, 11, 5616-5629.

30. Lourenço-de-Oliveira, R.; Honório, N.A.; Castro, M.G.; Schatzmayr, H.G.; Miagostovich, M.P.; Alves, J.C.R.; Silva, W.C.; Leite, P.J.; Nogueira, R. Dengue Virus Type 3 Isolation from Aedes aegypti in the Municipality of Nova Iguaçu, State of Rio de Janeiro. Mem. Inst. Oswaldo Cruz 2002, 97, 799-800.

31. Peyrefitte, C.N.; Couissinier-Paris, P.; Mercier-Perennec, V.; Bessaud, M.; Martial, J.; Kenane, N.; Durand, J.P.A.; Tolou, H.J. Genetic Characterization of Newly Reintroduced Dengue Virus Type 3 in Martinique (French West Indies). J. Clin. Microbiol. 2003, 41, 5195-5198.

32. Ensafi, A.A.; Heydari-bafrooei, E.; Amini, M. DNA-functionalized biosensor for riboflavin based electrochemical interaction on pretreated pencil graphite electrode. Biosens. Bioelectron. 2012, 31 , 376-381.

33. Hejazi, M.S.; Alipour, E.; Pournaghi-Azar, M.H. Immobilization and voltammetric detection of human interleukine-2 gene on the pencil graphite electrode. Talanta 2007, 71, 1734-1740. 
34. Pournaghi-Azar, M.H.; Alipour, E.; Zununi, S. Direct and rapid electrochemical biosensing of the human interleukin-2 DNA in unpurified polymerase chain reaction (PCR)-amplified real samples. Biosens. Bioelectron. 2008, 24, 524-530.

35. Özcan, A.; Yücel, S. A novel approach for the determination of paracetamol based on the reduction of $N$-acetyl- $p$-benzoquinoneimine formed on the electrochemically treated pencil graphite electrode. Anal. Chim. Acta 2011, 685, 9-14.

36. Ermini, M.L.; Scarano, S.; Bini, R.; Banchelli, M.; Berti, D.; Mascini, M.; Minunni, M. A rational approach in probe design for nucleic acid-based biosensing. Biosens. Bioelectron. 2011, 26, 4785-4790.

37. Huang, J.; Yang, X.; He, X.; Wang, K.; Liu, J.; Shi, H.; Wang, Q.; Guo, Q.; He, D. Design and bioanalytical applications of DNA hairpin-based fluorescent probes. TrAC Trends Anal. Chem. 2014, 53, 11-20.

38. O’Brien, B.; Zeng, H.; Polyzos, A.A.; Lemke, K.H.; Weier, J.F.; Wang, M.; Zitzelsberger, H.F.; Weier, H.U.G. Bioinformatics tools allow targeted selection of chromosome enumeration probes and aneuploidy detection. J. Histochem. Cytochem. 2013, 61, 134-147.

39. Campos-Ferreira, D.S.; Souza, E.; Nascimento, G.; Zanforlin, D.; Arruda, M.; Beltrão, M.; Melo, A.; Bruneska, D.; Lima-Filho, J.L. Electrochemical DNA biosensor for the detection of human papillomavirus E6 gene inserted in recombinant plasmid. Arab. J. Chem. 2014, doi:10.1016/ j.arabjc.2014.05.023.

40. Corrigan, D.K.; Schulze, H.; McDermott, R.A.; Schmüser, I.; Henihan, G.; Henry, J.B.; Bachmann, T.T.; Mount, A.R. Improving electrochemical biosensor performance by understanding the influence of target DNA length on assay sensitivity. J. Electroanal. Chem. 2014, 732, 25-29.

41. Soares, R.O.S.; Caliri, A. Stereochemical features of the envelope protein Domain III of dengue virus reveals putative antigenic site in the five-fold symmetry axis. Biochim. Biophys. Acta 2013, $1834,221-230$.

42. Weaver, S.C.; Brault, A.C.; Kang, W.; John, J. Genetic and Fitness Changes Accompanying Adaptation of an Arbovirus to Vertebrate and Invertebrate Cells Genetic and Fitness Changes Accompanying Adaptation of an Arbovirus to Vertebrate and Invertebrate Cells. J. Virol. 1999, 73, 4316-4326.

43. Bennett, S.N.; Holmes, E.C.; Chirivella, M.; Rodriguez, D.M.; Beltran, M.; Vorndam, V.; Gubler, D.J.; McMillan, W.O. Molecular evolution of dengue 2 virus in Puerto Rico: Positive selection in the viral envelope accompanies clade reintroduction. J. Gen. Virol. 2006, 87, 885-893.

44. Weaver, S.C.; Vasilakis, N. Molecular evolution of dengue viruses: Contributions of phylogenetics to understanding the history and epidemiology of the preeminent arboviral disease. Infect. Genet. Evol. 2009, 9, 523-540.

45. Wang, Q.; Ding, Y.; Gao, F.; Jiang, S.; Zhang, B.; Ni, J.; Gao, F. A sensitive DNA biosensor based on a facile sulfamide coupling reaction for capture probe immobilization. Anal. Chim. Acta 2013, $788,158-164$.

46. Zhang, L.; Wang, Y.; Chen, M.; Luo, Y.; Deng, K.; Chen, D.; Fu, W. A new system for the amplification of biological signals: RecA and complimentary single strand DNA probes on a leaky surface acoustic wave biosensor. Biosens. Bioelectron. 2014, 60, 259-264. 
47. Mohamadi, M.; Mostafavi, A.; Torkzadeh-Mahani, M. Electrochemical determination of biophenol oleuropein using a simple label-free DNA biosensor. Bioelectrochemistry 2015, 101C, 52-57.

48. Erdem, A.; Muti, M.; Karadeniz, H.; Congur, G.; Canavar, E. Colloids and Surfaces B: Biointerfaces Electrochemical monitoring of indicator-free DNA hybridization by carbon nanotubes - Chitosan modified disposable graphite sensors. Colloids Surf. B Biointerfaces 2012, 95, 222-228.

49. Paleček, E.; Fojta, M.; Tomschik, M.; Wang, J. Electrochemical biosensors for DNA hybridization and DNA damage. 1998, 13, 621-628.

50. Wang, J. Electrochemical biosensors: Towards point-of-care cancer diagnostics. Biosens. Bioelectron. 2006, 21, 1887-92.

51. Campos-Ferreira, D.S.; Nascimento, G.A.; Souza, E.V.M.; Souto-maior, M.A.; Arruda, M.S.; Zanforlin, D.M.L.; Ekert, M.H.F.; Bruneska, D.; Lima-filho, J.L. Electrochemical DNA biosensor for human papillomavirus 16 detection in real samples. Anal. Chim. Acta 2013, 804, 258-263.

52. Gao, Z.; Yang, W.; Wang, J.; Yan, H.; Yao, Y.; Ma, J.; Wang, B.; Zhang, M.; Liu, L. Electrochemical synthesis of layer-by-layer reduced graphene oxide sheets/polyaniline nanofibers composite and its electrochemical performance. Electrochim. Acta 2013, 91, 185-194.

53. Lucarelli, F.; Marrazza, G.; Palchetti, I.; Cesaretti, S.; Mascini, M. Coupling of an indicator-free electrochemical DNA biosensor with polymerase chain reaction for the detection of DNA sequences related to the apolipoprotein E. Anal. Chim. Acta 2002, 469, 93-99.

54. Teles, F.R.R.; Fonseca, L.P.Trends in DNA biosensors. Talanta, 2008, 77, 606-623.

55. Tichoniuk, M.; Ligaj, M.; Filipiak, M. Application of DNA Hybridization Biosensor as a Screening Method for the Detection of Genetically Modified Food Components. Sensors 2008, 8, 2118-2135.

56. Liu, X.; Fan, Q.; Huang, W. DNA biosensors based on water-soluble conjugated polymers. Biosens. Bioelectron. 2011, 26, 2154-2164.

57. Gumustas, M.; Ozkan, S.A. The Role of and the Place of Method Validation in Drug Analysis Using Electroanalytical Techniques. Open Anal. Chem. J. 2011, 5, 1-21.

58. Nascimento, G.A.; Souza, E.V.M.; Campos-ferreira, D.S.; Arruda, M.S.; Castelletti, C.H.M.; Wanderley, M.S.O.; Ekert, M.H.F.; Bruneska, D. Electrochemical DNA biosensor for bovine papillomavirus detection using polymeric film on screen-printed electrode. Biosens. Bioelectron. 2012, 38, 61-66.

59. Aydoğdu, G.; Günendi, G.; Zeybek, D.K.; Zeybek, B.; Pekyardımcı, Ş. A novel electrochemical DNA biosensor based on poly-(5-amino-2-mercapto-1,3,4-thiadiazole) modified glassy carbon electrode for the determination of nitrofurantoin. Sens. Actuators B Chem. 2014, 197, 211-219.

60. Wang, J.; Kawde, A. Pencil-based renewable biosensor for label-free electrochemical detection of DNA hybridization. Anal. Chim. Acta 2001, 431, 219-224.

61. Sehatnia, B.; Golabi, F.; Sabzi, R.E.; Hejazi, M.S. Modeling of DNA Hybridization Detection Using Methylene Blue as an Electroactive Label. J. Iran. Chem. Soc. 2011, 8, 115-122.

62. Souza, E.; Nascimento, G.; Santana, N.; Campos-ferreira, D.; Bibiano, J.; Arruda, M.S. Electrochemical DNA Biosensor for Sequences Related to the Human Papillomavirus Type 16 using Methylene Blue. Biosens. J. 2014, 3, 3-7. 
63. Ren, Y.; Deng, H.; Shen, W.; Gao, Z. A Highly Sensitive and Selective Electrochemical Biosensor for Direct Detection of MicroRNAs in Serum. Anal. Chem. 2013, 9, 4784-4789.

64. Auer, S.; Nirschl, M.; Schreiter, M.; Vikholm-Lundin, I. Detection of DNA hybridisation in a diluted serum matrix by surface plasmon resonance and film bulk acoustic resonators. Anal. Bioanal. Chem. 2011, 400, 1387-1396.

65. Gong, P.; Lee, C.; Gamble, L.J.; Castner, D.G.; Grainger, D.W.; Chem, L.J. A. Hybridization Behavior of Mixed DNA/Alkylthiol Monolayers on Gold: Characterization by Surface Plasmon Resonance and $32 \mathrm{P}$ Radiometric Assay rescence intensity measurements reported in a related. 2006, 78, 3326-3334.

(C) 2015 by the authors; licensee MDPI, Basel, Switzerland. This article is an open access article distributed under the terms and conditions of the Creative Commons Attribution license (http://creativecommons.org/licenses/by/4.0/). 